Institut für Veterinärpathologie

der Vetsuisse-Fakultät Universität Zürich

Direktorin: Prof. Dr. med. vet. Anja Kipar

Immunohistochemical expression of Bax and Bak in canine non-neoplastic tissues

\author{
Inaugural-Dissertation \\ zur Erlangung der Doktorwürde der \\ Vetsuisse-Fakultät Universität Zürich \\ vorgelegt von \\ Martina Croci \\ Tierärztin \\ von Mendrisio TI, Schweiz \\ genehmigt auf Antrag von \\ Prof. med. vet. Franco Guscetti, Referent
}

Zürich 2013 


\section{Inhaltsverzeichnis}

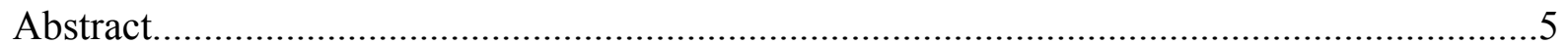

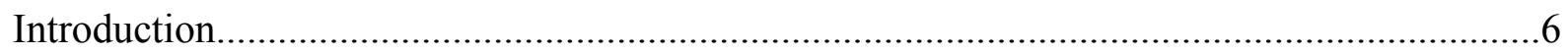

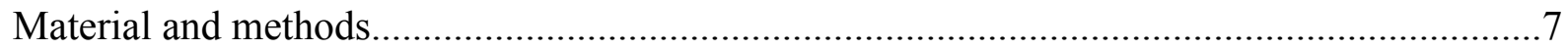

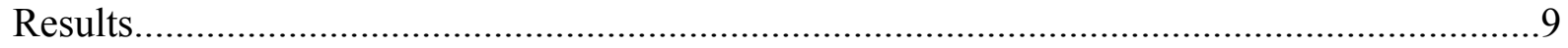

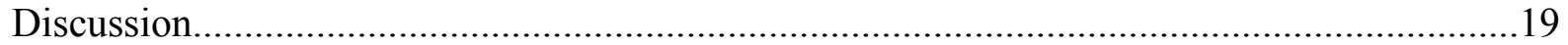

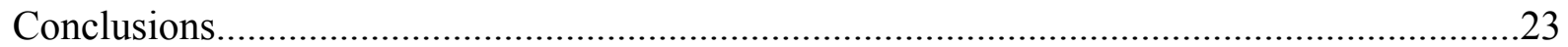

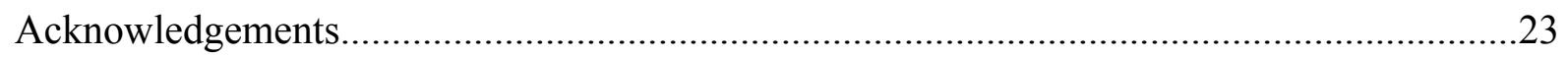

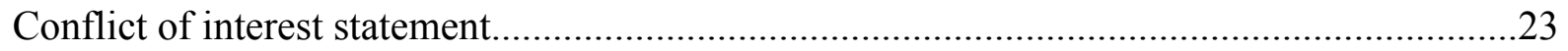

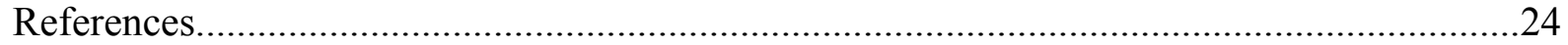

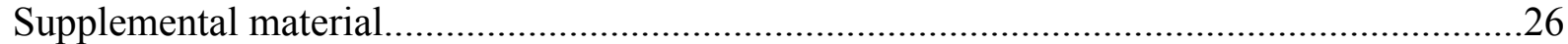

Danksagung

Curriculum Vitae

The following text is published in the Veterinary Journal

M. Croci, M. Dettwiler, L. Vaughan, F. Guscetti. Immunohistochemical expression of Bax and Bak in canine non-neoplastic tissues. Vet. $\mathrm{J}$; in press, available online 26.8.2013, doi: 10.1016/j.tvj1.2013.07.029. 


\title{
Immunohistochemical expression of BAX and Bak in canine non-neoplastic tissues
}

\begin{abstract}
Apoptosis is critical for embryonic development, maintenance of tissue homeostasis and protection against malignant transformation. The Bcl-2 family of proteins plays a key role in intrinsic apoptosis by controlling the integrity of the outer mitochondrial membrane, and the multidomain pro-apoptotic Bcl-2 family members Bax and Bak are essential components of this pathway. The aim of this study was to provide data on the expression of these proteins in normal canine tissues. Two antibodies against Bax recognising different conformations of the protein and one antibody against Bak were validated by immunohistochemistry and immunoblotting using canine recombinant proteins and keratinocytes treated with ultraviolet light. The antibodies were used immunohistochemically to label a wide panel of histologically normal tissues assembled on tissue microarrays. In addition, a subset of the tissues was evaluated by Western blot analysis.

Immunohistochemical and Western blot analyses revealed that both Bax and Bak are widely expressed in non-neoplastic tissues from adult dogs. Immunohistochemistry showed almost exclusively cytoplasmic labelling and prominent labelling of epithelial cells. In lymph nodes, immunohistochemical labelling was diffuse for both proteins and showed enhanced intensities in the mantle zones for Bax and the germinal centres for Bak. Strong reactivity for the active conformation of Bax was detected only in enterocytes and Leydig cells and in scattered lymphocytes. These data indicate widespread expression of Bax and Bak in normal canine tissues. Knowledge of the expression of Bax and Bak in normal tissues is a prerequisite in assessing the role of these proteins in canine neoplastic disease.
\end{abstract}

Keywords: Apoptosis; Bak; BAX; Dog; Epithelial; Immunohistochemistry; Normal tissue; UV-light; Western blot. 


\section{Introduction}

Apoptosis is a genetically controlled cell death program critical for embryonic development, maintenance of tissue homeostasis and protection against malignant transformation (Cory et al., 2003; Elmore, 2007). Two main apoptotic pathways are known, the extrinsic or death-receptor pathway, which is triggered by extracellular ligands, and the intrinsic or mitochondrial pathway. Intrinsic apoptosis is induced by many different intracellular signals and is regulated by the Bcl-2 protein family, which controls the integrity of the outer mitochondrial membrane (OMM) through interactions between members of its three major subgroups. One group comprises the effector multidomain pro-apoptotic members BAX (BCL2-associated X protein) and Bak (BCL2-homologous antagonist/killer) that are gateway proteins essential to intrinsic apoptosis (Wei et al., 2001). Upon an adequate proapoptotic stimulus, BAX and Bak are activated, change their conformation and BAX translocates from the cytoplasm to the OMM, where Bak already resides. There they form homooligomeric pores which allow the release into the cytosol of cytochrome $\mathrm{c}$ and other proteins that induce the demise of the cell (Letai, 2008). The members of the anti-apoptotic subgroups (with Bcl-2 as the prototype) can bind BAX and Bak hindering their activation. Proteins of the third subgroup, the BH3-only proteins inhibit the anti-apoptotic proteins and, under some circumstances, can directly activate BAX or Bak (Cory et al., 2003).

Studies with knock-out animals suggest an extensive functional overlap between Bax and Bak but also their combined functions to be essential for normal development (Knudson et al., 1995; Lindsten et al., 2000). Expression studies in humans based either on mRNA or protein assays, including immunohistochemistry, point to a widespread tissue distribution of these two proteins (Oltvai et al., 1993; Krajewski et al., 1994; Kiefer et al., 1995; Krajewski et al., 1996). This notion is supported by immunohistochemical data from a publicly accessible repository (The Human Protein Atlas ${ }^{1}$ ). Accordingly, BAX is most strongly expressed in the epithelial cells of the gastrointestinal tract and trachea, urothelium, renal tubuli, breast, and prostate gland, in the testis and endocrine glands (thyroid, parathyroid and adrenal glands). Similarly, Bak is most strongly expressed in epithelial cells of the epidermis, gastrointestinal tract and trachea, urothelium, as well as in the lymphatic system and adrenal gland (Oltvai et al., 1993; Krajewski et al., 1994; Kiefer et al., 1995; Krajewski et al., 1996; The Human Protein Atlas $\left.{ }^{1}\right)$.

Deregulation of apoptosis is a recognised mechanism contributing to tumorigenesis and resistance to therapy. Three specific blocks of apoptosis have been postulated at the level

\footnotetext{
${ }^{1}$ The Human Protein Atlas, http://www.proteinatlas.org (version 11, accessed august 2011)
} 
of the Bcl-2 family of proteins, including (1) overexpression of anti-apoptotic members; (2) functional impairment or expression loss of key $\mathrm{BH} 3$-only proteins, or functional impairment or expression loss of BAX and Bak (Letai, 2008). Thus, knowledge about the expression of these proteins in non-neoplastic tissues is necessary to characterize their role in tumorigenesis. To our knowledge, there is no immunohistochemical data available yet on the expression of BAX and Bak in normal canine tissues. The present tissue microarray (TMA)-based study using thoroughly validated antibodies against total BAX, activated BAX and total Bak, contributes to closing this gap. Catalogues of the immunohistochemical expression of these proteins, partially validated through western blot analyses, are provided for future reference e.g. in oncological studies.

\section{Material and methods}

\section{Recombinant proteins}

cDNAs coding for canine Bak (GenBank accession number AAY19401) and Bax (sequence identical to GenBank BAC56139) cloned into a pGEX4t2 vector (Invitrogen) were available from a concomitant study (de Brot et al., unpublished data). They were expressed as fusion proteins with N-terminal glutathione S-transferase (GST) in BL21 Star E. coli (Invitrogen) as described previously (Keller et al., 2007). For western blot analysis, lysates from liquid cultures of bacteria expressing GST-Bak or GST-BAX were purified using glutathione Sepharose beads as described previously (Wimmershoff et al., 2010). For immunohistochemistry, bacteria fixed for $24 \mathrm{~h}$ in $4 \%$ neutral buffered formaldehyde were embedded in paraffin wax (Wimmershoff et al., 2010). To create a representative array, cylinders of $0.6 \mathrm{~mm}$ diameter (cores) of each paraffin block containing bacteria were transferred to a recipient block using a manual tissue arrayer (Beecher Instruments).

\section{Cultured keratinocytes}

Canine normal keratinocytes (Bskin cell line) were grown in Dulbecco's Modified Eagles medium, irradiated with $100 \mathrm{~mJ}$ UVC light using a cross linker, harvested and processed for western blot analysis and immunohistochemistry as described by Dettwiler et al. (2013).

\section{Canine tissues}

For immunohistochemical analysis, TMAs containing normal organs originating each from at least three different adult dogs were available (Wimmershoff et al., 2010). Two 
additional TMAs were assembled with various organs and lymph nodes, respectively, all freshly sampled from seven further dogs euthanised in the context of an unrelated experiment. These animals were free of neoplastic disease. All tissues were fixed in $4 \%$ neutral buffered formaldehyde for $24 \mathrm{~h}$, routinely embedded into paraffin wax, and were free of histopathological lesions (i.e. normal). Whole sections of skin and lymph nodes were used to confirm TMA findings. For western blot analysis, selected tissues of these dogs were snap frozen in liquid nitrogen and stored at $-80{ }^{\circ} \mathrm{C}$.

\section{Antibodies}

Commercially available antibodies against human BAX and Bak were selected based on homology of the immunogen with the canine sequences and/or reactivity with recombinant canine proteins. They included: (1) a rabbit polyclonal anti-BAX antibody clone A20 (DB005, Delta Biolabs; immunogen: amino acids (aa) 11-30) denominated henceforth BAXAbA20; (2) a mouse monoclonal anti-BAX antibody clone 2D2 (MS-711-P0, NeoMarkers; immunogen: aa 3-16) called henceforth BAX-Ab2D2; and (3) a polyclonal anti-Bak antibody 06-535 (Upstate; immunogen: aa 22-38) denominated henceforth Bak-AbNT. In addition, anti- $\beta$-actin antibody ab8227 (Abcam) was used to normalize western blot results.

\section{Western blots}

The procedure was performed as described by Dettwiler et al. (2013), but with slight modifications. Equal amounts $(100 \mu \mathrm{g})$ of protein for each sample were measured with NanoDrop (Thermo Fisher Scientific) and diluted in a sodium dodecyl sulfate (SDS) loading buffer, run in $15 \%$ SDS gels and blotted onto PVDF membranes. Primary antibodies BakAbNT $(0.5 \mu \mathrm{g} / \mathrm{mL})$ or BAX-AbA20 $(0.5 \mu \mathrm{g} / \mathrm{mL})$ or BAX-Ab2D2 $(0.4 \mu \mathrm{g} / \mathrm{mL})$ or ab8227 $(0.3$ $\mu \mathrm{g} / \mathrm{mL}$ ) were applied for either $1 \mathrm{~h}$ at room temperature or over night at $4{ }^{\circ} \mathrm{C}$. Polyclonal and monoclonal antibodies were diluted in Tris-buffered saline and 0.1\% Tween 20 (TBST) containing $1 \%$ skimmed milk or $1 \%$ BSA, respectively. Secondary antibodies, either goat anti-mouse-horseradish peroxidase (HRP) labelled (Geno Technologies) or goat anti-rabbitHRP labelled (Jackson ImmunoResearch), were applied in a 1:7500 dilution. Negative controls included omitting the primary antibody and antibody preincubation were performed as described below in the antibody preincubation section. 


\section{Immunohistochemistry}

Sections of $2 \mu \mathrm{m}$ were deparaffinized, rinsed in deionised water and subjected to antigen retrieval consisting of heating in a steamer (Pascal S2800, Dako) in EDTA buffer, pH9.0, for $20 \mathrm{~min}$ at $98{ }^{\circ} \mathrm{C}$ (Bak-AbNT and BAX-AbA20), and for $2 \mathrm{~min}$ at $125^{\circ} \mathrm{C}(\mathrm{BAX}-$ Ab2D2). Primary antibodies diluted in Antibody Diluent (S2002, Dako) were incubated in a moist chamber $1 \mathrm{~h}$ at room temperature for BAX-Ab2D2 $(2 \mu \mathrm{g} / \mathrm{mL})$ and Bak-AbNT $(0.5$ $\mu \mathrm{g} / \mathrm{mL})$ or over night at $4{ }^{\circ} \mathrm{C}$ for BAX-AbA20 $(2 \mu \mathrm{g} / \mathrm{mL})$. Peroxidase.blocking solution (S2023, Dako) was applied for $10 \mathrm{~min}$. The signal was visualized using the DAKO Detection kit (Detection system, Dako) according to the manufacturer's instructions. Negative controls included omitting the primary antibody and antibody preincubation as described below in the next section. The immunohistochemical reactions were scored based on labelling intensities as follows: $0=$ signal absent, $0.5=$ very weak, $1=$ weak, $2=$ moderate, and $3=$ strong signal.

\section{Antibody preincubation}

Polyclonal antibodies Bak-AbNT and BAX-AbA20 were mixed by inversion over night at $4{ }^{\circ} \mathrm{C}$ with purified GST-Bak or GST-BAX at a 100:1 antigen-antibody ratio, respectively, as described (Wimmershoff et al., 2010) and used as preincubated negative control for immunohistochemistry.

\section{Results}

Antibodies against human BAX and Bak, polyclonal BAX-AbA20 and Bak-AbNT and monoclonal BAX-Ab2D2, also recognise canine BAX and Bak expressed as GlutathioneS-Transferase (GST) fusion proteins in bacteria. In western blots (Fig. 1A), all antibodies labelled bands corresponding to the full-length products (BAX: $55 \mathrm{kDa}$; Bak: $57 \mathrm{kDa}$, although the latter product was inconsistently present) and degradation products (as deduced from reactivity with an anti-GST antibody, not shown). Furthermore, immunohistochemistry with formalin-fixed, paraffin-embedded bacteria showed that all antibodies specifically reacted with formalin-resistant canine epitopes (Fig. 1B).

Upon staining keratinocytes, BAX-AbA20 elicited a weak cytoplasmic punctate to diffuse signal that was enhanced after UV treatment (Fig. 1C). BAX-Ab2D2 elicited no signal in untreated, non-apoptotic cells and a strong, granular cytoplasmic signal in treated apoptotic cells (Fig. 1C). Western blot analysis with BAX-Ab2D2 revealed a specific band (21 kDa) that was more pronounced after irradiation (Fig. 1D). Bak-AbNT showed a cytoplasmic punctate immunohistochemical signal that was enhanced after UV-treatment (Fig. 1C). 
Western blot analysis revealed a specific band $(24 \mathrm{kDa})$ that was enhanced in treated cells (Fig. 1D). Data from a detailed time course experiment documenting enhancement of the signals after UV-treatment is reported in Appendix A, Supplementary material.

A

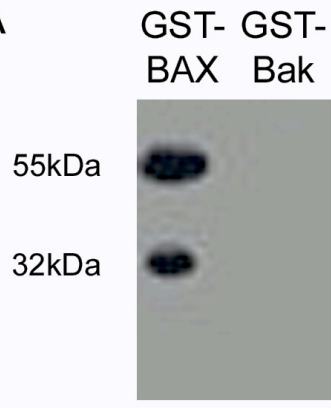

$\mathrm{BAX}-\mathrm{AbA20}$

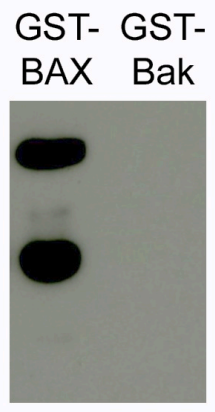

BAX-Ab2D2
GST- GSTBAX Bak

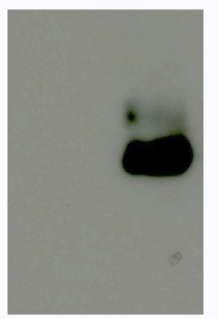

Bak-AbNT

C

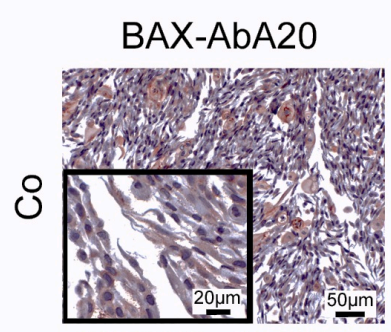

BAX-Ab2D2

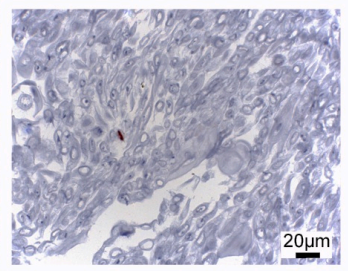

\section{Bak-AbNT}

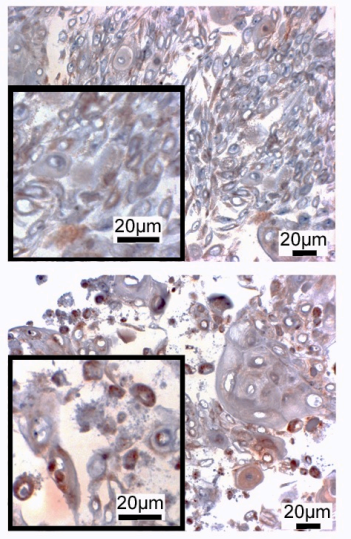

B

\section{BAX Bak}

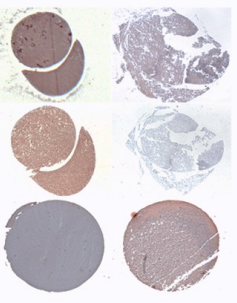

BAX-AbA20

BAX-Ab2D2

Bak-AbNT
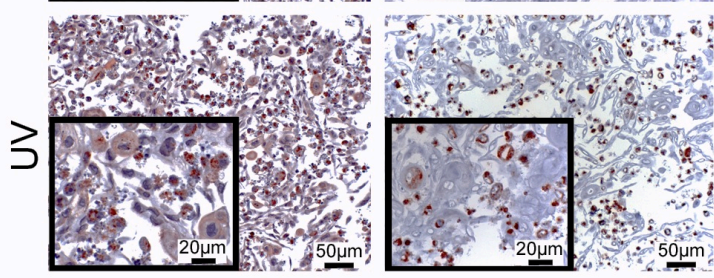

$46 \mathrm{kDa}$

$34 \mathrm{kDa}$

D

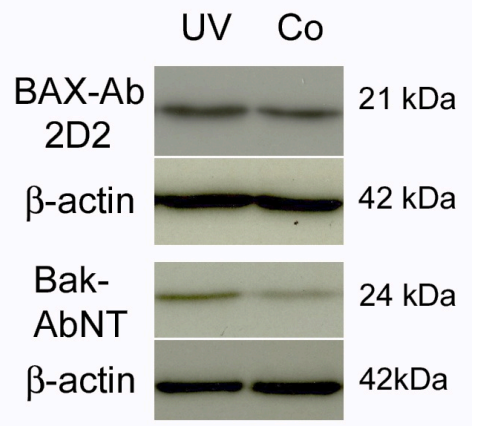

Fig. 1 Validation of Bax-AbA20, BAX-Ab2D2 and Bak-AbNT antibodies using (A, B) recombinant canine proteins and $(C, D)$ cultured canine keratinocytes

A. Western blots with lysates of bacteria expressing indicated Glutathione-S-Transferase (GST) fusion protein; B. Immunohistochemistry with formalin-fixed, paraffin-embedded bacteria $(0.6 \mathrm{~mm}$ cores $)$ expressing indicated GST fusion protein; C. Immunohistochemistry of canine cultured keratinocytes collected at $12 \mathrm{~h}$ after irradiation (UV) and non-irradiated controls (Co). All reactions were done using indicated antibodies; all immunohistochemical reactions visualized with AEC chromogen, hematoxylin counterstain; D. Western blots with lysates of keratinocytes collected at $12 \mathrm{~h}$ after irradiation (UV) and non-irradiated controls (Co).

The antibodies were specific for canine BAX and Bak and labelled these proteins at physiological levels, with labelling intensities appearing to be proportional to the intracellular protein amounts detected. More importantly, BAX-Ab2D2 appeared to label immunohistochemically a form of BAX present only in cells committed to apoptosis.

Using normal canine organs in TMAs, labelling with BAX-AbA20 was observed almost exclusively in the cytoplasm (Table 1). The signal intensities ranged from moderate to 


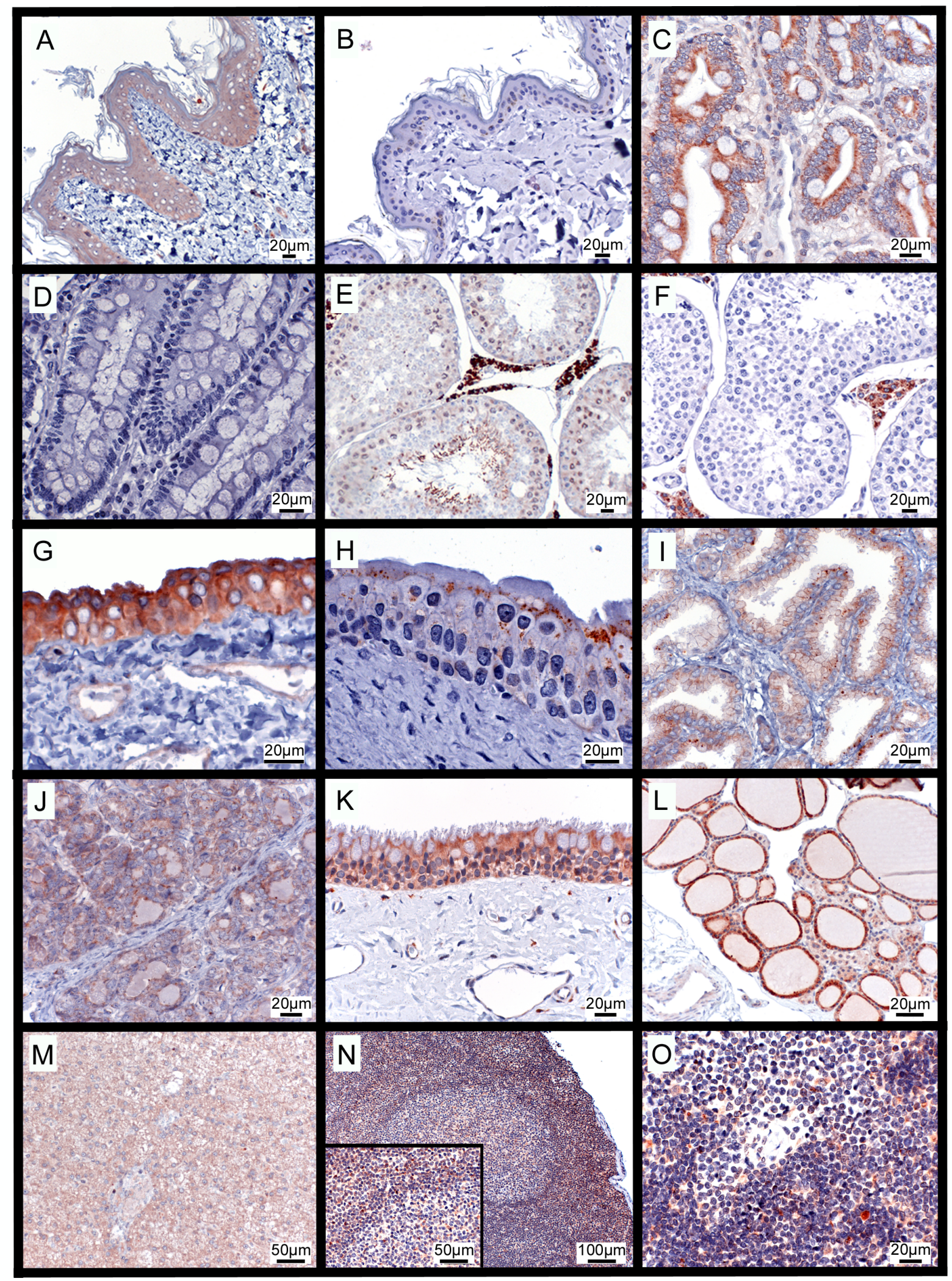

Fig. 2 Immunohistochemistry of canine tissues using BAX-AbA20 antibody

A. Skin: epidermis diffusely labelled with weak-to-moderate intensity; B. Skin, BAX-AbA20 preabsorbed with GST-BAX protein: complete absence of signal; C. Small intestine: strong labelling of enterocytes; D. Small intestine, BAX-AbA20 preabsorbed: complete absence of signal; E. Testis: Leydig's cells strongly labelled, weak-to-moderate cytoplasmic and intranuclear signal in most spermatic maturation stadia; F. Testis, BAXAbA20 preabsorbed: residual signal in the Leydig's cells; G. Urethra: labelling intensity gradient from weak (basal) to strong (apical) throughout all urothelial layers; H. Urinary bladder, BAX-AbA20 preabsorbed: residual 
Cont'd Fig2. granular signal in the apical urothelial cells; I. Prostata: weak-to-moderate labelling of epithelial cells; J.Mammary gland: weak labelling of epithelial cells; K. Trachea: gradient from moderate (basal) to strong (apical)throughout the epithelium; L. Thyroid: strong labelling of follicular epithelial cells; M. Liver: weak-tomoderate labelling of hepatocytes; N. Lymph node (cortex): labelling strong in the mantle zone and interfollicular region and weak in the germinal center; insert: detail view of the boundary between germinal center, mantle zone, and interfollicular region; O. Lymph node (medulla): weakly labelled lymphocytes. All reactions visualized with AEC chromogen, hematoxylin counterstain.

Table 1. Immunohistochemical expression of BAX in canine non-neoplastic tissues

\begin{tabular}{|c|c|c|c|c|c|}
\hline \multirow[b]{2}{*}{$\begin{array}{l}\text { Organ } \\
\text { system }\end{array}$} & \multirow[b]{2}{*}{ Organ } & \multirow[b]{2}{*}{ Cell type } & \multicolumn{3}{|c|}{$\begin{array}{l}\text { Signal intensity score with indicated } \\
\text { antibody }\end{array}$} \\
\hline & & & BAX-AbA20 & BAX-Ab2D2 & $\begin{array}{l}\text { Bax-AbA20 } \\
\text { preabsorbe } \\
\text { d }\end{array}$ \\
\hline \multirow[t]{3}{*}{ Integument } & Skin & Epidermis & 2 & $0.5(<1 \%)^{\mathrm{e}}$ & 0 \\
\hline & & Sweat/Sebaceous glands & 0 & $0-2$ & 0 \\
\hline & & Fibroblasts & 0 & 0 & 0 \\
\hline \multirow[t]{11}{*}{ Digestive } & Esophagus & Epithelial cells & 2 & $0-0.5$ & 0 \\
\hline & Salivary glands & Serous acini & $1-2$ & $0.5-1$ & 0 \\
\hline & & Mucous acini & $1-2$ & $0.5-1$ & 0 \\
\hline & Stomach & Parietal cells & $2^{\mathrm{i}}$ & $2^{\mathrm{i}}$ & $2^{\mathrm{i}}$ \\
\hline & & Chief cells & 0 & 0 & 0 \\
\hline & $\begin{array}{l}\text { Small intestine } \\
\text { (duodenum, jejunum) }\end{array}$ & Enterocytes & 1 to $2-3^{a}$ & $2-3^{a}$ & 0 \\
\hline & & $\begin{array}{l}\text { Smooth muscle } \\
\text { (L. muscularis ) }\end{array}$ & 0 & 0 & 0 \\
\hline & & Brunner's glandular cells & 0 & 0 & 0 \\
\hline & Large intestine & Enterocytes & $1-2$ & $0-3^{a}$ & 0 \\
\hline & Liver & Hepatocytes and stellate cells & $1-2$ & $0.5-1$ & 0 \\
\hline & Pancreas & endocrine and exocrine & 0.5 & 0.5 & 0 \\
\hline \multirow[t]{5}{*}{ Respiratory } & Trachea & Epithelial cells & $2-3^{b}$ & $0-3^{b}$ & 0 \\
\hline & & Submucosal fibroblasts & 0 & 0 & 0 \\
\hline & Bronchi & Epithelial cells & $0.5-1$ & 0 & 0 \\
\hline & Alveoli & Pneumocytes & 0 & 0 & 0 \\
\hline & & Macrophages & $1-2$ & $0.5-2$ & 0 \\
\hline \multirow[t]{6}{*}{ Urinary } & Kidney & Glomeruli & $0-0.5$ & 0 & 0 \\
\hline & & Proximal tubules & $1-3^{i}$ & $1-2^{\mathrm{i}}$ & $1-2^{\mathrm{c}, \mathrm{i}}$ \\
\hline & & Distal tubules & $2-3^{i}$ & $1-2^{i}$ & $1-2^{\mathrm{c}, \mathrm{i}}$ \\
\hline & Bladder & Epithelial cells & $1-2^{b, c}$ & $0.5-1^{\mathrm{a}}$ & $\underset{\mathrm{d}, \mathrm{e}}{1-2}(<5 \%)$ \\
\hline & & Smooth muscle & $0-0.5$ & 0 & 0 \\
\hline & Urethra & Epithelial cells & $2-3^{b}$ & $0-1$ & 0 \\
\hline \multirow[t]{7}{*}{ Reproductive } & Ovary & Parenchyma & $0-0.5^{c}$ & $0-1$ & n.a. \\
\hline & & Connective tissue & 0 & 0 & n.a. \\
\hline & Uterus & Endometrium & $0.5-2$ & 2 & n.a. \\
\hline & & Myometrium & 0 & 0 & n.a. \\
\hline & & Stroma & 0 & 0 & n.a. \\
\hline & Mammary gland & Glandular epithelial cells & $1^{\mathrm{e}}$ & 0 & 0 \\
\hline & & Myoepithelial cells & 0 & 0 & 0 \\
\hline
\end{tabular}




\begin{tabular}{|c|c|c|c|c|c|}
\hline & Prostate gland & Glandular epithelial cells & $1-3$ & 0 & 0 \\
\hline & & Basal cell layer & $1-3$ & $0.5-1$ & 0 \\
\hline & Testis & Spermatogonia & $0.5-1^{\mathrm{g}}$ & 0 & 0 \\
\hline & & Spermatocytes & $0.5-1^{\mathrm{g}}$ & 0 & 0 \\
\hline & & Spermatids & $0.5-1^{\mathrm{g}}$ & 0 & 0 \\
\hline & & Sertoli cells & $0.5-1$ & $0-0.5(<5 \%)^{\mathrm{e}}$ & 0 \\
\hline & & Leydig's cells & $1-3$ & 3 & $1-2(<5 \%)$ \\
\hline & Vagina & Epithelial cells & $1-3^{a}$ & 0.5 & n.a. \\
\hline Muscular & Heart muscle & Cardiomyocytes & $0-0.5$ & 0 & n.a. \\
\hline & Skeletal muscle & Myocytes & 0 & 0 & 0 \\
\hline Lymphatic & Lymph node & Medullar lymphocytes & $0-1$ & $3(10-20 \%)^{e}$ & 0 \\
\hline & & Interfollicular lymphocytes & $0-1^{\mathrm{f}}$ & $3(10-20 \%)^{\mathrm{e}}$ & 0 \\
\hline & & Follicular germinal center & $0.5-1^{f}$ & $3(10-20 \%)^{e}$ & 0 \\
\hline & & Follicular mantle zone & $1-3^{\mathrm{f}}$ & $3(10-20 \%)^{\mathrm{e}}$ & 0 \\
\hline & & Macrophages & $2-3$ & 0 & $1-2$ \\
\hline & & Plasma cells & $2-3$ & 0 & $1-2$ \\
\hline & Bone marrow & All cell types & $1^{\mathrm{f}}$ & $3(50 \%)^{e}$ & 0 \\
\hline & Spleen & Parenchyma (red/white pulp) & $0-0.5$ & $3(10-20 \%)^{\mathrm{e}}$ & 0 \\
\hline & & Connective tissue & 0 & 0 & 0 \\
\hline & & $\begin{array}{l}\text { Leukocytes other than } \\
\text { lymphocytes }\end{array}$ & $2-3$ & 3 & 0 \\
\hline & Palatine tonsil & Lymphocytes & $0-3^{\mathrm{f}}$ & $3(10-20 \%)^{\mathrm{e}}$ & 0 \\
\hline & & Epithelial cells & $1-2$ & 0 & 0 \\
\hline & & Macrophages & 2 & 3 & 0 \\
\hline & Thymus & Lymphocytes & $0-0.5$ & $3(10-20 \%)^{\mathrm{e}}$ & 0 \\
\hline Endocrine & Adrenal gland & All cortical zones & 1 & 1 & 0 \\
\hline & & Medulla & 0 & 0 & 0 \\
\hline & Thyroid & Follicular and medullary cells & $2-3$ & 0 & 0 \\
\hline & Parathyroid & Glandular cells & 0.5 & 0 & 0 \\
\hline Nervous & $\begin{array}{l}\text { Spinal cord (various } \\
\text { regions) }\end{array}$ & Gray matter & $1(<5 \%)^{\mathrm{e}, \mathrm{h}}$ & 0 & n.a. \\
\hline & & White matter & 0 & 0 & n.a. \\
\hline & Brain (various regions) & Gray matter & $2(<5 \%)^{\mathrm{e}, \mathrm{h}}$ & 0 & n.a. \\
\hline & & White matter & 0 & 0 & n.a. \\
\hline & Cerebellum & Purkinje cells & 2 & 0 & n.a. \\
\hline & & Granular cells & 0 & 0 & n.a. \\
\hline${ }^{\mathrm{a}}$ : gradient fr & basal stronger to apical v & weaker & & & \\
\hline b. gradient fr & basal weaker to apical & ronger & & & \\
\hline c: additional & anular pattern (score $2-3$ ) & & & & \\
\hline d: exclusively & ranular pattern & & & & \\
\hline e: percentage & efer to approx. portion of & cells with indicated score & & & \\
\hline f: including $\mathrm{s}$ & ne (up to $20 \%$ ) stronger st & taining cells (score 2-3) & & & \\
\hline${ }^{\mathrm{g}}$ : in addition & uclear signal (score $0-3$ ) & & & & \\
\hline h. diffuse we & signal (score 0.5 ) of the $n$ & europil and axons & & & \\
\hline i: weak resid & signal (score 1 in the pa & etal cells and 0.5 elsewhere) & e negative & rol without pr & nary a \\
\hline
\end{tabular}




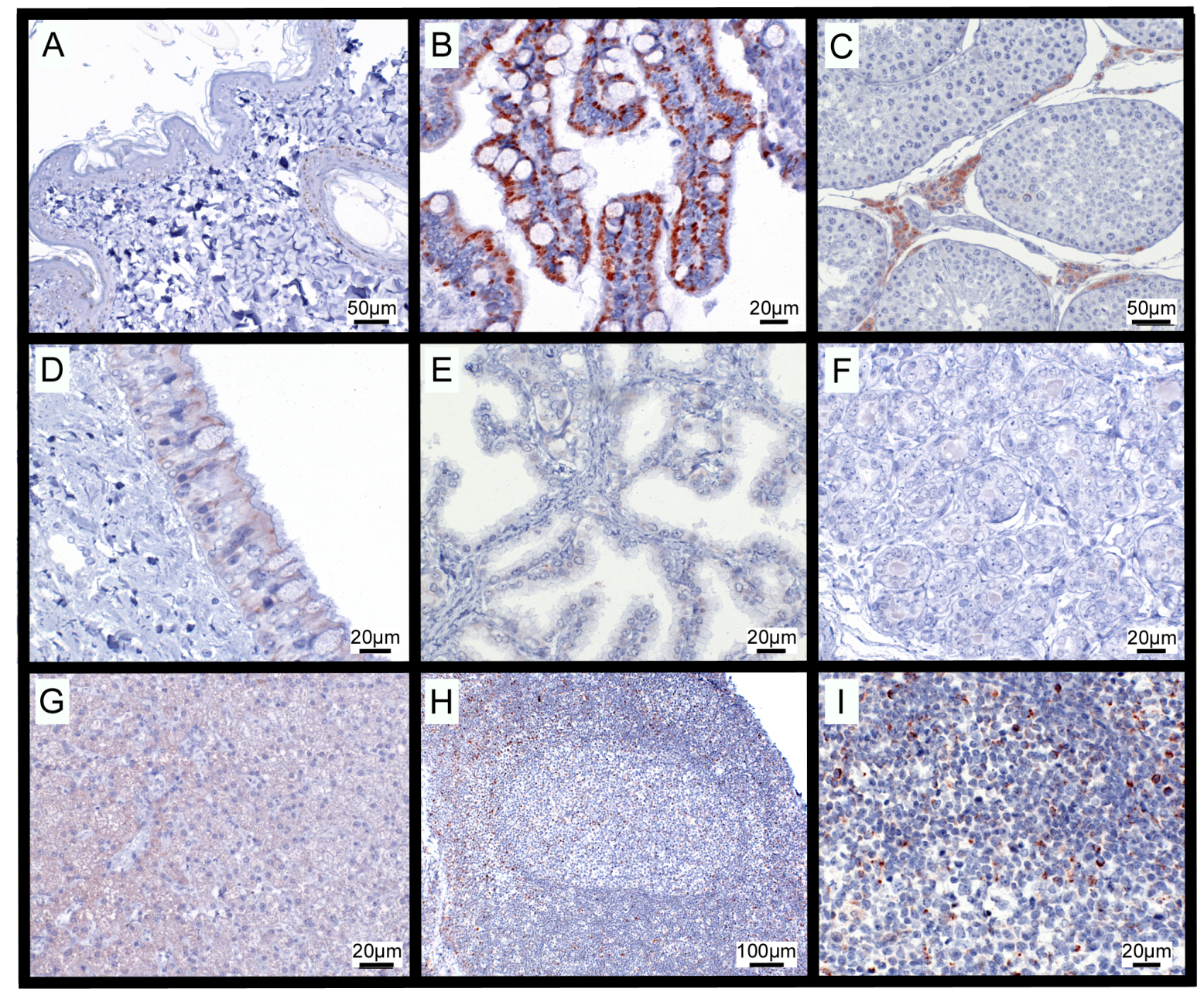

Fig. 3 Immunohistochemistry of canine tissues using BAX-Ab2D2 antibody

A. Skin: almost complete absence of signal in the epidermis; B. Small intestine: strong labelling of villous enterocytes; C. Testis: strong labelling of the Leydig's cells; D. Trachea: very weak signal in all epithelial cell layers; E. Prostata: almost complete absence of signal; F. Mammary gland: complete absence of signal; G. Liver: weakly labelled hepatocytes; H. Lymph node (cortex): strongly labelled scattered lymphocytes (approx. 10$20 \%$ ); I. Lymph node (medulla): strongly labelled scattered lymphocytes. All reactions visualized with AEC chromogen, hematoxylin counterstain. 
strong (score 2-3) in intestinal, urethral, urinary bladder and tracheal epithelia, and in Leydig's cells. An exception was a moderate to strong intranuclear signal in some of the spermatogonia and spermatocytes. A weak to moderate cytoplasmic signal (score 1-2) was observed in the epidermis, in esophagal, renal tubular and prostatic epithelia, and in fewer than $5 \%$ of the neurons, with only a weak signal evident (score $0-1$ ) in mammary gland epithelia and part of the spermatogonia and Sertoli cells (Fig. 2). Renal glomeruli and adrenal medulla were negative or very weakly labelled. The tracheal epithelium and the urothelium showed an intensity gradient increasing from basal to apical, while in the intestinal epithelium the gradient appeared to be inversed. In the lymph nodes BAX-AbA20 elicited a diffuse labelling of lymphocytes with enhanced intensity in the mantle zone. Negative controls showed occasional residual staining as detailed in Table 1 and Fig. 2.

BAX-Ab2D2 showed overall less reactivity than BAX-AbA20 (Table 1) and elicited a moderate to strong specific cytoplasmic signal only in enterocytes and Leydig's cells. A very weak signal was observed in tracheal, urinary bladder and urethral epithelia, prostatic basal cell layers and alveolar macrophages. In lymph nodes, BAX-Ab2D2 intensely labelled scattered individual cells accounting for $10-20 \%$ of lymphocytes (Fig. $3 \mathrm{H}$ and I). The remaining tissues were negative.

Immunoreactivity with Bak-AbNT was exclusively cytoplasmic (Table 2). The signal intensity ranged from moderate to strong in intestinal, urethral, mammary gland and tracheal epithelia, from weak to moderate in the epidermis and esophagal and prostatic epithelia and was weak in most of the spermatogonia, Sertoli cells and cardiomyocytes (Fig. 4). Neurons, renal glomeruli and adrenal medulla were negative or very weak. Labelling of whole skin sections elicited a diffuse cytoplasmic signal in all epidermal layers with intensities varying between samples from weak to moderate. Basal and spinous layers sometimes showed a superimposed punctate pattern with further cell types in the skin labelled variably, including endothelia of capillaries, fibroblasts and mast cells (Fig. 4A). The signal intensity in lymph node tissues was moderate to strong in germinal centers, moderate in the paracortex, and weak in the mantle zone and medullary cords (Fig. 4M-O). Results of the negative controls are detailed in Table 2 and Fig. 4.

These results indicated a widespread expression of BAX and Bak in canine adult normal tissues. Immunohistochemical reactivity with antibody BAX-Ab2D2, which in vitro reacted immunohistochemically mainly with keratinocytes committed to apoptosis was clearly weaker than that of the total BAX marker BAX-AbA20, with a few exceptions. 
Table 2. Immunohistochemical expression of Bak in canine non-neoplastic tissues

\begin{tabular}{|c|c|c|c|c|}
\hline \multirow[b]{2}{*}{ Organ system } & \multirow[b]{2}{*}{ Organ } & \multirow[b]{2}{*}{ Cell type } & \multicolumn{2}{|c|}{$\begin{array}{l}\text { Signal intensity score } \\
\text { indicated antibody }\end{array}$} \\
\hline & & & Bak-AbNT & $\begin{array}{l}\text { Bak-AbNT } \\
\text { preabsorbed }\end{array}$ \\
\hline \multirow[t]{3}{*}{ Integument } & Skin & Epidermis & $1-2$ & $0-0.5$ \\
\hline & & Sweat/Sebaceous glands & $1-2$ & 0 \\
\hline & & Fibroblasts & 2 & 0 \\
\hline \multirow[t]{12}{*}{ Digestive } & Esophagus & Epithelial cells & $1-2$ & 0 \\
\hline & Salivary glands & Serous acini & 1 & 0 \\
\hline & & Mucous acini & 2 & 0 \\
\hline & Stomach & Pits and necks & 0.5 & 0 \\
\hline & & Parietal cells & $3^{e}$ & $1^{\mathrm{e}}$ \\
\hline & & Chief cells & $0.5-1$ & 0 \\
\hline & $\begin{array}{l}\text { Small intesti } \\
\text { (duodenum, } \\
\text { jejunum) }\end{array}$ & Enterocytes & $2-3$ & 0 \\
\hline & & Smooth muscle (L. muscularis ) & $0.5-1$ & 0 \\
\hline & & Brunner's glandular cells & 0.5 & 0 \\
\hline & Large intestine & Enterocytes & $2-3$ & 0 \\
\hline & Liver & Hepatocytes and stellate cells & $1-2$ & $1-2$ \\
\hline & Pancreas & endocrine and exocrine & $1-2$ & 0 \\
\hline \multirow[t]{5}{*}{ Respiratory } & Trachea & Epithelial cells & 3 & 0 \\
\hline & & Submucosal fibroblasts & $0-3$ & 0 \\
\hline & Bronchi & Epithelial cells & $1-2$ & 0 \\
\hline & Alveoli & Pneumocytes & $0-1$ & 0 \\
\hline & & Macrophages & $1-3$ & 2 \\
\hline \multirow[t]{6}{*}{ Urinary } & Kidney & Glomeruli & 0 & 0 \\
\hline & & Proximal tubules & $2^{b, e}$ & $0.5-1^{\mathrm{b}, \mathrm{e}}$ \\
\hline & & Distal tubules & $2-3^{b, e}$ & $0.5-1^{\mathrm{b}, \mathrm{e}}$ \\
\hline & Bladder & Epithelial cells & $1-2^{a}$ & 0 \\
\hline & & Smooth muscle & 0.5 & 0 \\
\hline & Urethra & Epithelial cells & $2-3$ & 0 \\
\hline \multirow[t]{15}{*}{ Reproductive } & Ovary & Parenchyma & 1 & n.a. \\
\hline & & Connective tissue & $0(50 \%)-1^{d}$ & n.a. \\
\hline & Uterus & Endometrium & 2 & n.a. \\
\hline & & Myometrium & 0.5 & n.a. \\
\hline & & Stroma & 0 & n.a. \\
\hline & Mammary gland & Glandular epithelial cells & $2-3$ & 0 \\
\hline & & Myoepithelial cells & 0 & 0 \\
\hline & Prostate gland & Glandular epithelial cells & $0.5-1$ & 0 \\
\hline & & Basal cell layer & $2-3$ & 0 \\
\hline & Testis & Spermatogonia & $0.5-1$ & 0 \\
\hline & & Spermatocytes & 0 & 0 \\
\hline & & Spermatids & 0 & 0 \\
\hline & & Sertoli cells & $0.5-1$ & 0 \\
\hline & & Leydig's cells & 2 & $\begin{array}{l}1-2 \\
\text { (only granules) }\end{array}$ \\
\hline & Vagina & Epithelial cells & $1-2^{a}$ & n.a. \\
\hline
\end{tabular}




\begin{tabular}{|c|c|c|c|c|}
\hline \multirow[t]{2}{*}{ Muscular } & Heart muscle & Cardiomyocytes & $0.5-1$ & n.a. \\
\hline & Skeletal muscle & Myocytes & 0.5 & 0 \\
\hline \multirow[t]{14}{*}{ Lymphatic } & Lymph node & Medullar lymphocytes & 0.5 & 0 \\
\hline & & Interfollicular lymphocytes & $1-2$ & 0 \\
\hline & & Follicular germinal center & 2 & 0 \\
\hline & & Follicular mantle zone & 1 & 0 \\
\hline & & Macrophages & $2-3$ & 2 \\
\hline & & Plasma cells & $0-2$ & 0 \\
\hline & Bone marrow & All cell types & $1-3(50 \%)^{d}$ & 0 \\
\hline & Spleen & Parenchyma (red/white pulp) & 0.5 & 0 \\
\hline & & Connective tissue & 0.5 & 0 \\
\hline & & Leukocytes other than lymphocytes & 0.5 & 0 \\
\hline & Palatine tonsil & Lymphocytes & $0-1$ & 0 \\
\hline & & Epithelial cells & $1-2$ & 0 \\
\hline & & Macrophages & 3 & 0 \\
\hline & Thymus & Lymphocytes & $0-1$ & 0 \\
\hline \multirow[t]{6}{*}{ Endocrine } & Adrenal gland & Zona glomerulosa & $2-3^{b}$ & $0.5-1$ \\
\hline & & Zona fasciculata & $2^{b}$ & $0.5-1$ \\
\hline & & Zona reticularis & $2^{\mathrm{b}}$ & $0.5-1$ \\
\hline & & Medulla & $0-0.5$ & 0 \\
\hline & Thyroid & Follicular and medullary cells & $2-3$ & 0.5 \\
\hline & Parathyroid & Glandular cells & 1 & 0 \\
\hline \multirow[t]{6}{*}{ Nervous System } & $\begin{array}{l}\text { Spinal cord (various } \\
\text { regions) }\end{array}$ & Gray matter & $0^{\mathrm{c}}$ & n.a. \\
\hline & & White matter & $0^{\mathrm{c}}$ & n.a. \\
\hline & $\begin{array}{l}\text { Brain (various } \\
\text { regions) }\end{array}$ & Sray matter & $0^{\mathrm{c}}$ & n.a. \\
\hline & & White matter & $0^{\mathrm{c}}$ & n.a. \\
\hline & Cerebellum & Purkinje cells & 0 & n.a. \\
\hline & & Granular cells & 0 & n.a. \\
\hline
\end{tabular}

a: gradient from basal stronger to apical weaker

${ }^{\mathrm{b}}$ : additional granular pattern (score 2-3)

': diffuse weak signal (score 0.5 ) of the neuropil and axons

${ }^{\mathrm{d}}$ : percentages refer to approx. portion of cells with indicated score

e: a weak residual signal (score 1 in the parietal cells and 0.5 elsewhere) is present in the negative control without primary antibody

n.a. $=$ not available 


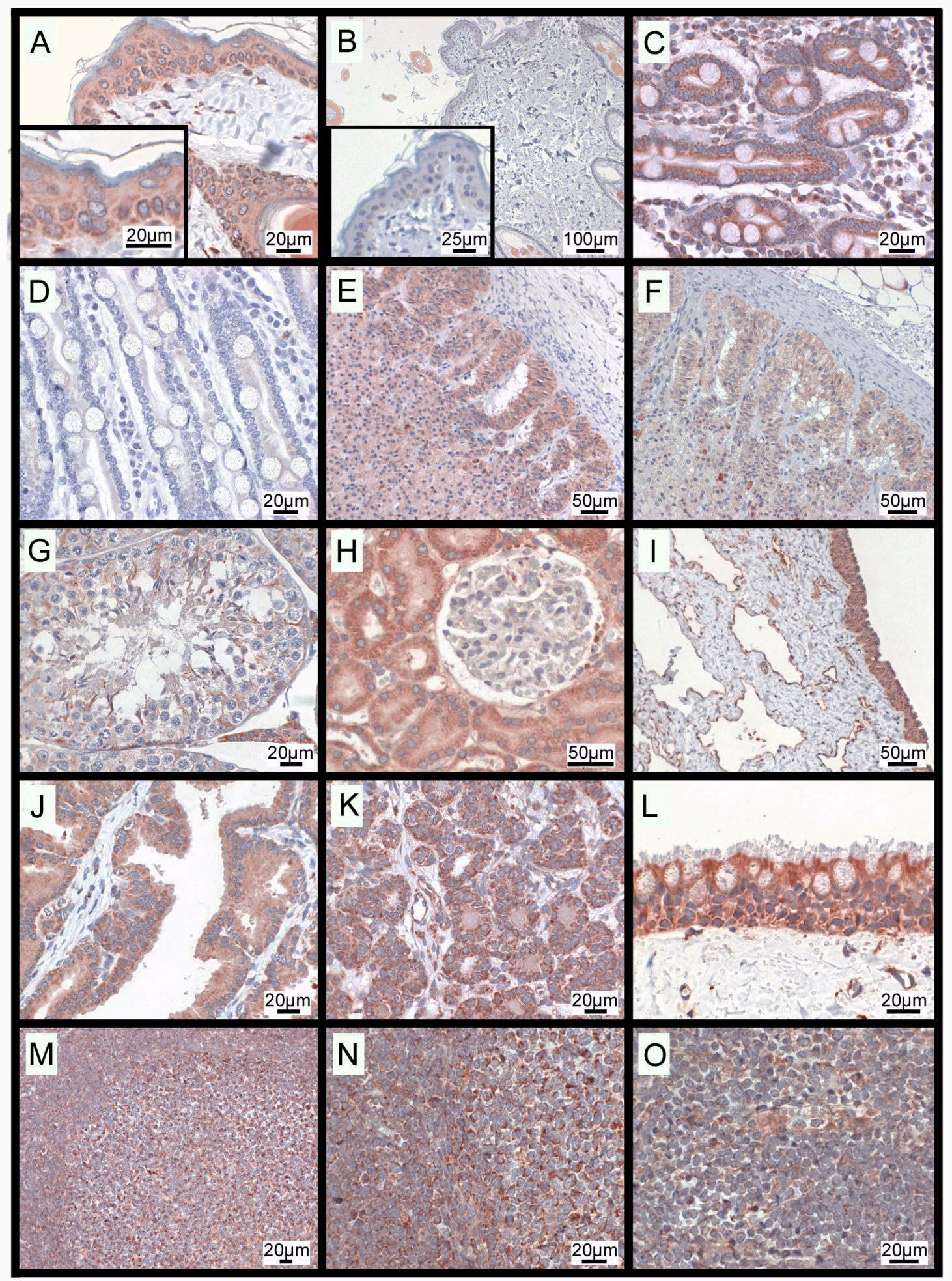

Fig. 4 Immunohistochemistry of canine tissues using Bak-AbNT antibody

A. Skin: epidermis diffusely labelled; B. Skin, replicate immunohistochemistry using BakAbNT preabsorbed with GST-Bak: almost complete absence of signal; C. Small intestine: strongly labelled enterocytes; D. Small intestine, Bak-AbNT preabsorbed with GST-Bak fusion protein: complete absence of signal; E. Cortical adrenal gland: moderate labelling; F. Cortical adrenal gland, Bak-AbNT preabsorbed: weak residual signal; G. Testis: labelling strong in the Leydig's cells and weak in some maturation stages of spermatids and in Sertoli cells; $\mathrm{H}$. Kidney: tubuli strongly labelled, glomerulum almost negative; I. Urethra: moderate-to-strong labelling of all layers of the urothelium; J. Prostata: weak-to-moderate labelling of the glandular cells; K. Mammary gland: moderate-to-strong labelling of the glandular cells; L. Tracheal epithelium: strong labelling; M. Lymph node (cortex): moderate-to-strong labelling of the germinal center lymphocytes; N. Lymph node (cortex): detail view 
of the boundary between germinal center and mantle zone showing differences in signal intensity between the Cont'd Fig4. two regions; O. Lymph node (medulla): weak labelling of the lymphocytes. All reactions visualized with AEC chromogen, hematoxylin counterstain.

Lysates of selected organs were analysed by immunoblotting to further support the immunohistochemical findings. Western blot analysis of skin lysates showed specific bands supporting the notion that these tissues express both BAX and Bak (Fig. 5A). Identity of the $24 \mathrm{kDa}$ band was confirmed with an additional anti-Bak antibody not otherwise used due to low affinity (not shown). In contrast to keratinocytes, in whole skin lysates Bak-AbNT additionally cross-reacted with 50 and $70 \mathrm{kDa}$ products (Fig. 5A, 3rd panel, lane 2), indicating that there may be cross-reactions outside of the epidermal compartment.

Analysis of lysates of further tissues showed a very good agreement between both anti-BAX antibodies (Fig. 5B) and suggested a limited propensity to react unspecifically for BAX-AbA20 varying between organs and minimal for instance in palatine tonsil and lymph node lysates. The relative signal intensities of BAX-AbA20 matched well between immunoblotting and immunohistochemistry. Analysis of the same tissues with Bak-AbNT showed overall presence of a specific band (Fig. 5B). A further $70 \mathrm{kDa}$ band was especially marked in extracts of liver, tonsil, lymph node and musculature and weak in spleen, kidney and testis. In summary, western blot analyses supported the notion that BAX and Bak are widely expressed in canine non-neoplastic tissues and confirmed the immunohistological findings for BAX.

\section{Discussion}

In this study, an immunohistochemical expression analysis of pro-apoptotic BAX and Bak was conducted in normal canine tissues with the aim of providing comprehensive catalogues of the expression of these proteins. The present data indicate that both BAX and Bak, similar to previous reports on human tissues (Oltvai et al., 1993; Krajewski et al., 1994; Kiefer et al., 1995; Krajewski et al., 1996), are expressed at high levels in epithelial cells or tissues containing epithelia in the dog and suggest that both proteins have a role in these organs under physiological conditions. In some epithelia, as for instance enterocytes (BAX) and the urothelium (Bak), a gradient of reactivity paralleling cell differentiation was observed. A possible role of these proteins in the differentiation and/or turnover of these tissues has been suggested (Krajewski et al., 1996; Penault-Llorca et al., 1998; Gao and Wang, 2009). In contrast to some studies with human tissues (Tomková et al., 1998; Batinac et al., 2007), but in agreement with others (Krajewski et al., 1994; Penault-Llorca et al., 1998), no gradient was 
observed for BAX in the canine epidermis. Similarly, no gradient was observed for Bak in the canine colon, skin, trachea, and prostate gland, in contrast to descriptions of some human studies (Krajewski et al., 1996; Tomková et al., 1998; Batinac et al., 2007; Duckworth and

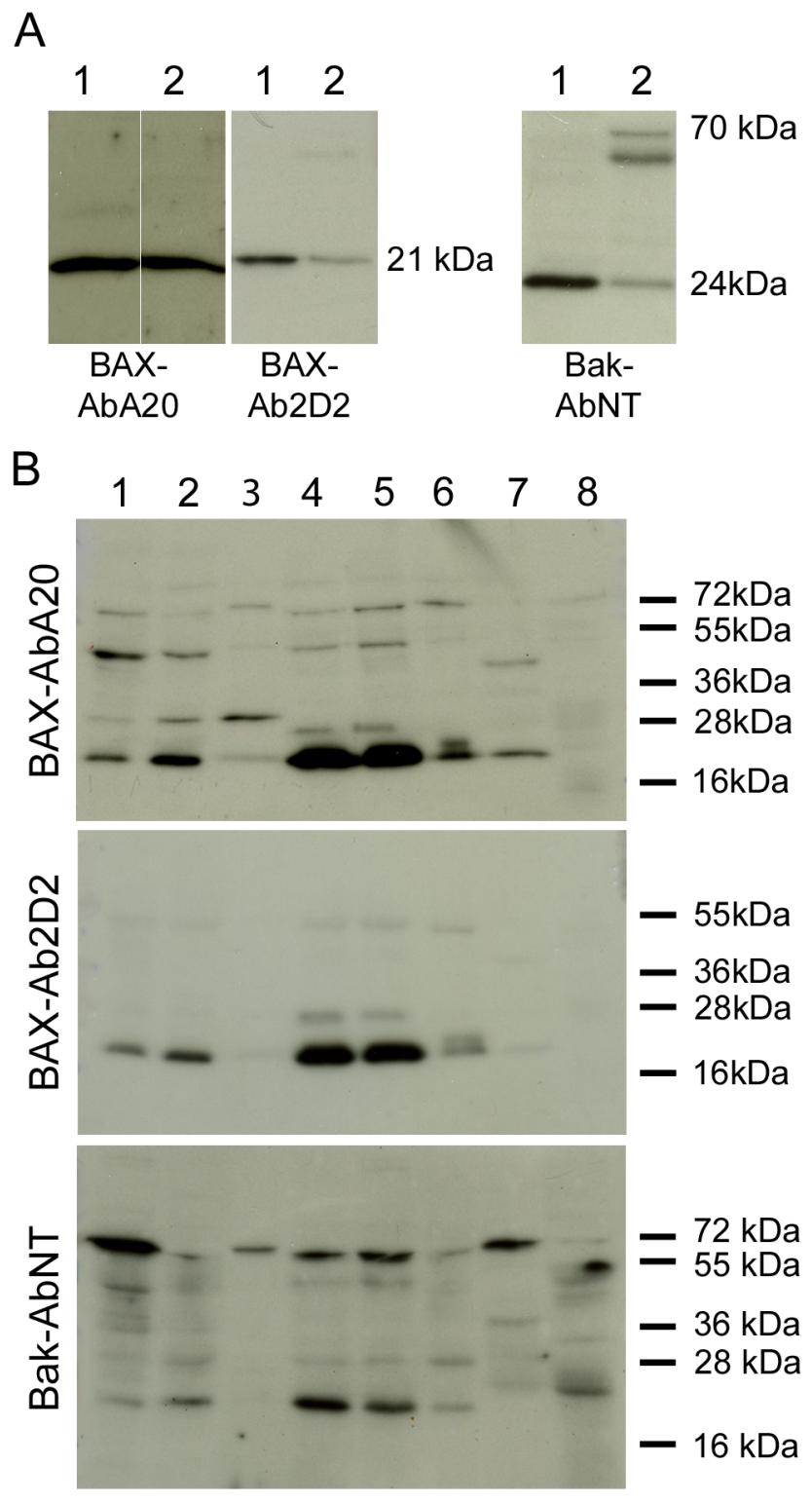

Fig. 5 Western blot analysis of BAX and Bak expression in canine tissues and cultured keratinocytes A. Western blots of canine cultured keratinocytes (lane 1) and canine skin (lane 2) with indicated antibodies; all antibodies label a band of expected size (BAX: $21 \mathrm{kDa}$; Bak: $24 \mathrm{kDa})$ in all panels; in skin lysate (3rd panel, lane 2) Bak-AbNT additionally labels bands at 50 and $70 \mathrm{kDa}$; B. Western blot of canine tissues: lane 1: liver; lane 2: kidney; lane 3: spleen; lane 4: tonsil; lane 5: lymph node; lane 6: testis; lane 7: skeletal musculature; lane 8: pancreas. Both anti-BAX antibodies label a specific marked band at $21 \mathrm{kDa}$ (lanes 1, 2, 4, 5, 6, 7) and weak bands at $26 \mathrm{kDa}$ (lanes 4,5) and $23 \mathrm{kDa}$ (lane 6) interpreted as BAX isoforms; polyclonal BAX-AbA20 weakly labels additional bands at 28, 40 and $70 \mathrm{kDa}$ in some organs. Labelling with Bak-AbNT antibody variably shows two major bands at $24 \mathrm{kDa}$ (corresponding to the expected size of Bak) and $70 \mathrm{kDa}$. An occasional faint additional band around $50 \mathrm{kDa}$ (1st and 3rd panel) was attributed, at least partially, to the secondary antibody (not shown). All reactions were done using indicated antibodies. 
Pritchard, 2009). The ability to demonstrate such gradients may depend upon technical factors such as the antibody concentration. Other possible causes of inter-study differences include differences in antibodies, antigen retrieval and visualization methods.

It is noteworthy in this context that BAX-AbA20 labelling in canine lymph nodes was stronger in the mantle zone than in the germinal centers, as confirmed using whole sections. This contrasts with human and murine reports indicating either a stronger expression in the germinal centers compared to the remaining regions (Krajewski et al., 1994; Penault-Llorca et al., 1998; Agarwal and Naresh, 2002) or no differences between the lymph node compartments (The Human Protein Atlas ${ }^{1}$ ). The expression of Bak in canine lymph nodes was stronger in germinal centers than in interfollicular regions, similar to some studies with human tissues (Agarwal and Naresh, 2002) but unlike others indicating either predominance of labelling in the mantle zone (Krajewski et al., 1996) or no differences (The Human Protein Atlas $^{1}$ ). This underlines the importance of species specific studies to establish normal distributions as a basis for interpreting pathological changes in disease.

Knowledge of the expression of apoptotic-related proteins in normal tissues is a prerogative to study their role in disease. Defects in the regulation of apoptosis have been described in various diseases including autoimmune and degenerative disorders, as well as cancer (Elmore, 2007). The expression data for the multidomain pro-apoptotic proteins BAX and Bak, which are essential for intrinsic apoptosis, and the reagents for their detection in canine tissues presented here provide useful tools for future studies of such diseases. For instance, the alteration of the expression of several apoptosis-related proteins including BAX and/or Bak has been implicated in the genesis, progression and resistance to therapy of several cancer types under experimental conditions and in spontaneous disease (Cory et al., 2003; Deng et al., 2007; Olejniczak et al., 2008; Duckworth and Pritchard, 2009). Thus, assessment of the expression of these proteins might be important to characterize the pathogenesis of these diseases and, in future, to inform therapeutic interventions.

Since the use of antibodies raised against heterologous antigens, which is a recurrent situation in studies including companion animals, can be problematic (Keller et al., 2007; Dettwiler et al., 2013) and BAX-Ab2D2 does not cross-react with murine BAX (Hsu and Youle, 1997), all antibodies used here were thoroughly validated. They were formally demonstrated to react with the recombinant canine homologues and to label endogenous levels of protein in a semi-quantitative manner in UV-irradiated keratinocytes. Moreover, substantial differences in the immunohistochemical reactivities between the two anti-BAX antibodies were apparent. BAX-AbA20 and BAX-Ab2D2 bind different N-terminal epitopes 
of BAX (within amino acid (aa) 11-30 (first alpha-helix) and aa 3-16, respectively). BAXAbA20 immunohistochemically labelled both non-irradiated and irradiated cells, while BAXAb2D2 only labelled irradiated keratinocytes undergoing apoptosis, as described in nonneoplastic human skin exposed to UV-light (Zuliani et al., 2008).

This study suggested that BAX-Ab2D2 recognizes an epitope accessible immunohistochemically only in the active BAX conformation. Western blot data and the widespread punctate immunohistochemical labelling pattern observed with BAX-Ab2D2 in canine tissues support this notion. However, the real basis of this reactivity is not clear, since in biochemical studies antibodies against the very N-terminal end, such as clone 2D2, bound BAX independently of its conformation (Hsu and Youle, 1997). Intriguingly, Lalier et al. (2011) reported that antibodies targeting a region roughly corresponding to the immunogen of BAX-AbA20 only reacted with active BAX, while in another study both types of antibodies labelled BAX only after staurosporine treatment (Makin et al., 2001). The present findings and those of a previous immunohistochemical study indicate, however, that antibodies such as BAX-AbA20 label total BAX in tissues (Zuliani et al., 2007).

To the best of our knowledge this is the first immunohistochemical analysis of a wide range of tissues using antibodies directed against different conformations of BAX. Interestingly, most organs were negative or very weakly positive for BAX-Ab2D2, although in some cell types (i.e. enterocytes, Leydig's cells), a marked reactivity was observed. This might indicate the presence of activated BAX in these tissues.

We document here the widespread expression of BAX and Bak in normal canine tissues based on immunohistochemical analysis and supported by western blot data of the corresponding tissue extracts. Whereas immunoblot analysis indicated high levels of specificity for BAX-Ab2D2 and BAX-AbA20, there were varying levels of specificity between tissues for Bak-AbNT. Concomitant analysis of skin and keratinocytes indicated presence of a cross-reacting protein outside of the epidermal compartment but pointed to a specific labelling of the epidermis. Thus, although western blot analysis showed Bak protein to be present in all tissues analysed, further investigations are required to unequivocally identify the cell types expressing Bak. Such studies could include either the separate analysis of isolated tissue components or the use of antibodies against different epitopes of Bak or complementary methods such as in situ hybridisation. We identified an additional antibody cross-reacting with canine Bak that could not be used due to low affinity (not shown).

Besides its value for antibody validation and for confirming immunhistochemical findings, western blot analysis might also be useful to explain intriguing findings. One of 
these was the presence, in maturation stages of spermatids only, of an intranuclear immunohistochemical signal detected using BAX-AbA20. This was the only instance of intranuclear BAX labelling in this study and this finding is in agreement with a previous investigation of human testes (Oldereid et al., 2001). The presence of two distinct bands specific for BAX (at 21 and $23 \mathrm{kDa}$ ) in the western blot of canine testicular extracts point to the occurrence of different isoforms of the protein which might have different subcellular localizations in this tissue.

\section{Conclusions}

Widespread expression of the pro-apoptotic proteins BAX and Bak was found in canine normal tissues. The immunohistochemical signals were almost exclusively cytoplasmic and were particularly prominent in epithelial cells. In addition, enterocytes and Leydig's cells, as well as scattered lymphocytes were markedly labelled by an antibody likely recognizing the active conformational form of BAX in tissues. The detailed catalogues of the expression of these proteins in canine tissues provided here are usable references for studies investigating apoptosis-related diseases.

\section{Conflict of interest statement}

None of the authors of this paper has a financial or personal relationship with other people or organizations that could inappropriately influence or bias the content of the paper. MC received partial financial support through a grant from Bayer HealthCare (Bayer Vital $\mathrm{GmbH})$. Bayer HealthCare (Bayer Vital $\mathrm{GmbH}$ ) played no role in the study design or in the collection, analysis and interpretation of data, or in the decision to submit the manuscript for publication.

\section{Acknowledgements}

We are very grateful to Sabina Wunderlin for excellent technical help. We are indepted to Prof. EJ. Müller and Prof. MM. Suter, University of Berne, Switzerland, for providing the Bskin cell line. The financial support from Bayer HealthCare is kindly acknowledged. 


\section{References}

Agarwal B., Naresh K.H., 2002. Bcl-2 Family of Proteins in indolent B-Cell Non-Hodgkin's Lymphoma: Study of 116 Cases. American Journal of Hematology 70, 278-282.

Batinac T., Zamolo G., Hadzisejdić I., Zauhar G., Brumini G., Ruzić A., Persić V., 2007. Expression of Bcl-2 family proteins in psoriasis. Croatian Medical Journal 48, 319-326.

Cory S., Huang D.C., Adams J.M., 2003. The Bcl-2 family: roles in cell survival and oncogenesis. Oncogene 22, 8590-8607.

Deng J., Carlson N., Takeyama K., Dal Cin P., Shipp M., Letai A., 2007. BH3 profiling identifies three distinct classes of apoptotic blocks to predict response to ABT-737 and conventional chemotherapeutic agents. Cancer Cell 12, 171-85.

Dettwiler M., Croci M., Vaughan L., Guscetti F., 2013. Immunohistochemical expression study of pro-apoptotic BH3-only protein Bad in canine non-neoplastic tissues and canine lymphomas. Veterinary Pathology. http://dx.doi.org/10.1177/0300985813478212.

Duckworth C.A., Pritchard D.M., 2009. Suppression of apoptosis, crypt hyperplasia, and altered differentiation in the colonic epithelia of bak-null mice. Gastroenterology 136, 943-952.

Elmore S., 2007. Apoptosis: a review of programmed cell death. Toxicological Pathology 35, 495516.

Gao C., Wang A.Y., 2009. Significance of increased apoptosis and Bax expression in human small intestinal adenocarcinoma. Journal of Histochemistry and Cytochemistry 57, 1139-1148.

Hsu Y.T., Youle R.J., 1997. Nonionic detergents induce dimerization among members of the Bcl-2 family. Journal of Biological Chemistry 272, 13829-13834.

Keller S.M., Schade B., Rickenbacher A.B., Brugnera E., Wergin M.C., Müller E.J., Suter M.M., Guscetti F., 2007. A comprehensive test system to identify suitable antibodies against p53 for immunohistochemical analysis of canine tissues. Journal of Comparative Pathology 137, 59-70.

Kiefer M.C., Brauer M.J., Powers V.C., Wu J.J., Umansky S.R., Tomei L.D., Barr P.J., 1995. Modulation of apoptosis by the widely distributed Bcl-2 homologue Bak. Nature 374, 736-739.

Knudson C.M., Tung K.S., Tourtellotte W.G., Brown G.A., Korsmeyer S.J., 1995. Bax-deficient mice with lymphoid hyperplasia and male germ cell death. Science 270, 96-99.

Krajewski S., Krajewska M., Shabaik A., Miyashita T., Wang H.G., Reed J.C., 1994. Immunohistochemical determination of in vivo distribution of Bax, a dominant inhibitor of Bcl2. American Journal of Pathology 145, 1323-1336.

Krajewski S., Krajewska M., Reed J.C., 1996. Immunohistochemical analysis of in vivo patterns of Bak expression, a proapoptotic member of the Bcl-2 protein family. Cancer research 56, 28492855.

Lalier L., Cartron P.F., Olivier C., Logé C., Bougras G., Robert J.M., Oliver L., Vallette F.M., 2011. Prostaglandins antagonistically control Bax activation during apoptosis. Cell Death and Differentiation 18, 528-537.

Letai A.G., 2008. Diagnosing and exploiting cancer's addiction to blocks in apoptosis. Nature Reviews Cancer 8, 121-132. 
Lindsten T., Ross A.J., King A., Zong W.X., Rathmell J.C., Shiels H.A., Ulrich E., Waymire K.G., Mahar P., Frauwirth K., Chen Y., Wei M., Eng V.M., Adelman D.M., Simon M.C., Ma A., Golden J.A., Evan G., Korsmeyer S.J., MacGregor G.R., Thompson C.B., 2000. The combined functions of proapoptotic Bcl-2 family members bak and bax are essential for normal development of multiple tissues. Molecular Cell 6, 1389-1399.

Makin G.V.J., Corfe B.M., Griffiths G.J., Thistletwaite A., Hickman J.A., Dive C., 2001. Damageinduced Bax N-terminal change, translocation to mitochondria and formation of Bax dimers/ complexes occur regardless of cell fate. The EMBO Journal 20, 6306-6315.

Oldereid N.B., Angelis P.D., Wiger R., Clausen O.P., 2001. Expression of Bcl-2 family proteins and spontaneous apoptosis in normal human testis. Molecular Human Reproduction 7, 403-408.

Olejniczak S.H., Hernandez-Ilizaliturri F.J., Clements J.L., Czuczman, 2008. Acquired resistance to rituximab is associated with chemotherapy resistance resulting from decreased Bax and Bak expression. Clinical Cancer research 14, 1550-1560.

Oltvai Z.N., Milliman C.L., Korsmeyer S.J., 1993. Bcl-2 heterodimerizes in vivo with a conserved homolog, Bax, that accelerates programmed cell death. Cell 74, 609-619.

Penault-Llorca F., Bouabdallah R., Devilard E., Charton-Bain M.C., Hassoun J., Birg F., Xerri .L, 1998. Analysis of BAX expression in human tissues using the anti-BAX, 4F11 monoclonal antibody on paraffin sections. Pathology-Research and Practice 194, 457-464.

Tomková H., Fujimoto W., Arata J., 1998. Expression of the bcl-2 homologue bax in normal human skin, psoriasis vulgaris and non-melanoma skin cancers. European Journal of Dermatology 8, 256-260.

Wei M.C., Zong W.X., Cheng E.H., Lindsten T., Panoutsakopoulou V., Ross A.J., Roth K.A., MacGregor G.R., Thompson C.B., Korsmeyer S.J., 2001. Proapoptotic BAX and BAK: A requisite Gateway to Mitochondrial Dysfunction and Death. Science 292, 727-730.

Wimmershoff J., Polkinghorne A., Grest P., Schade B., Marchal T., Keller S.M., Guscetti F., 2010. Immunohistochemical detection of survivin in canine lymphoma. Journal of Comparative Pathology 142, 311-322.

Zuliani T., Obriot H., Tual M., Lachmann-Weber N., Dumas M., Formstecher P., Polakowska R., Ratinaud M.H., 2008. Variable Bax antigenicity is linked to keratinocyte position within epidermal strata and UV-induced apoptosis. Experimental Dermatology 17, 125-132. 


\section{Appendix A: Supplemental material}

Can also be found at: http://dx.doi.org/10.1016/j.tvj1.2013.07.029.

\section{Immunohistochemical and western blot analysis of keratinocytes collected in a time course after treatment with UV light}

Antibodies BAX-AbA20, BAX-Ab2D2 and Bak-AbNT were used to label keratinocytes either untreated or treated with UV (100 mJ) and harvested at $30 \mathrm{~min}, 4 \mathrm{~h}, 8 \mathrm{~h}, 12 \mathrm{~h}$ and $24 \mathrm{~h}$ after treatment (Fig. S1). The majority of the cells underwent apoptosis and presented extensive immunohistochemical reactivity for cleaved caspase-3 (not shown) within $24 \mathrm{~h}$ of treatment. BAX-AbA20 elicited a faint immunohistochemical cytoplasmic punctate to diffuse signal in over $50 \%$ of the untreated cells (Fig. S1, first row), while BAX-Ab2D2 elicited no signal in untreated, non-apoptotic cells (Fig. S1, second row). Bak-AbNT showed a cytoplasmic punctate signal in untreated cells (Fig. S1, third row). Intensity of the immunohistochemical signal elicited by BAX-AbA20 appeared to be enhanced after treatment. This enhancement affected a large portion of cells showing morphological signs of apoptotic cell death. Of note, cells in an advanced state of dismantlement, i.e. with marked fragmentation of the nucleus, often were negative (Fig. S1, first row). Cells showing squamous differentiation presented in the controls and early after UV irradiation a faint diffuse cytoplasmic labelling with sometimes a moderate punctate pattern; at $12 \mathrm{~h}$ and, more pronounced, at $24 \mathrm{~h}$ after irradiation, a large number of these cells showed a much stronger multifocal cytoplasmic granular staining despite absence of morphological signs of cell death. Using BAX-Ab2D2, a strong, granular cytoplasmic signal became visible in treated cells showing morphological signs of apoptosis. The intensity of this signal did not noticeably increase with time, while the number of positive cells increased markedly from a few cells at $30 \mathrm{~min}$ to large numbers of cells at $12 \mathrm{~h}$ and $24 \mathrm{~h}$. Cells in an advanced state of dismantlement showed only a very faint signal. Most of the cells showing squamous differentiation failed to display a signal. Western blot analysis of cell lysates with antibody BAX-Ab2D2 revealed an increase of the amount of BAX after irradiation (Fig. S1B) in the 2 to 4-fold range after normalizing with $\beta$-actin (Fig. S1C). The BAX/ $\beta$-actin ratio was calculated after scanning and measuring the intensity of each band using the ImageJ program (http://rsb.info.nih.gov/ij/index.html).

Using Bak-AbNT, the intensity of the immunohistochemical signal was enhanced after treatment and especially in cells showing morphological signs of apoptotic cell death (Fig. S1A). In contrast, cells in an advanced state of dismantlement were negative. Cells showing squamous differentiation and not undergoing apoptosis showed a faint labelling independent of treatment. In a western blot, after normalizing with $\beta$-actin, the relative amount of Bak labelled by Bak-AbNT appeared to be approximatively increased by 2 -fold in treated cells compared to untreated cells (Fig. S1B and C). 

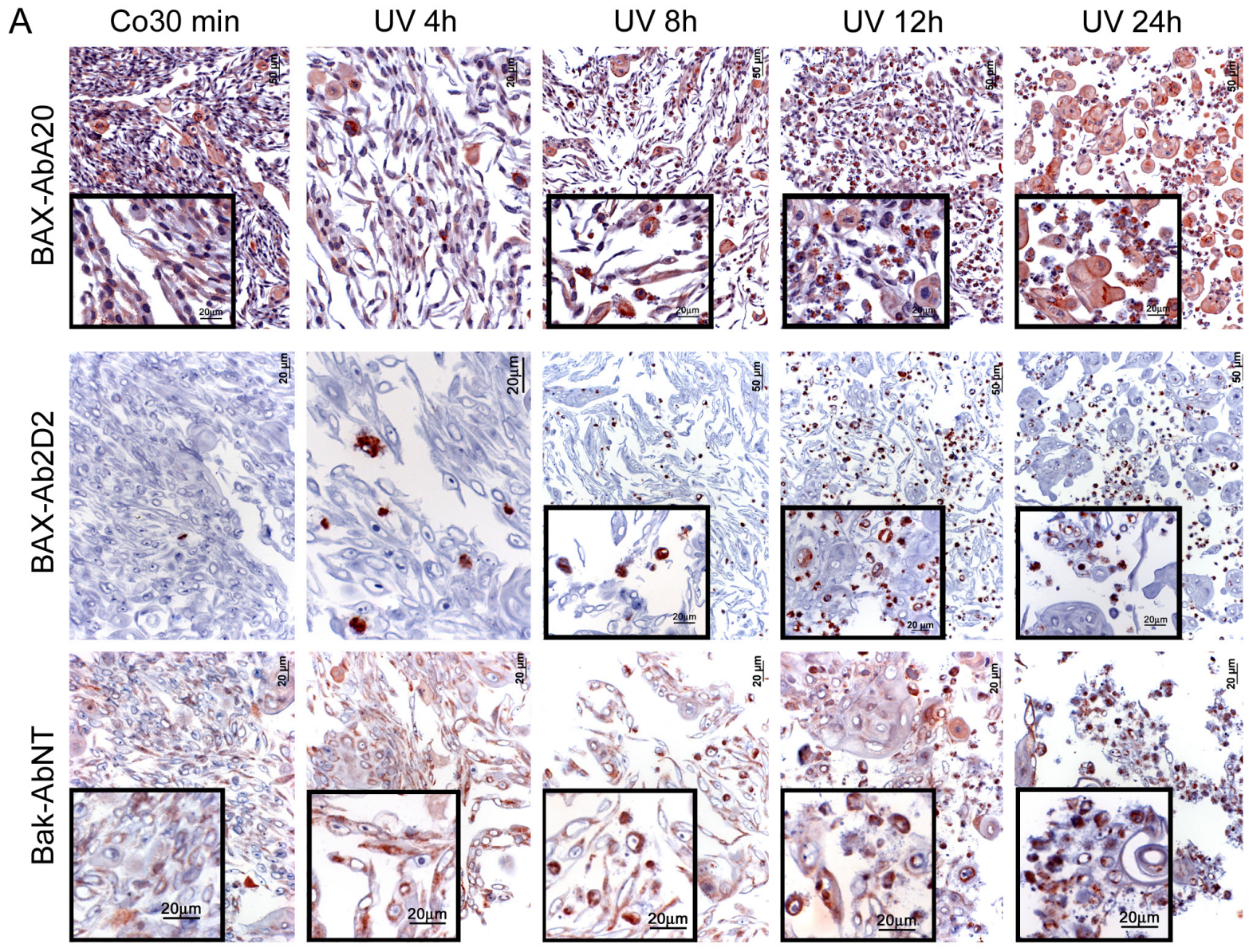

B

C
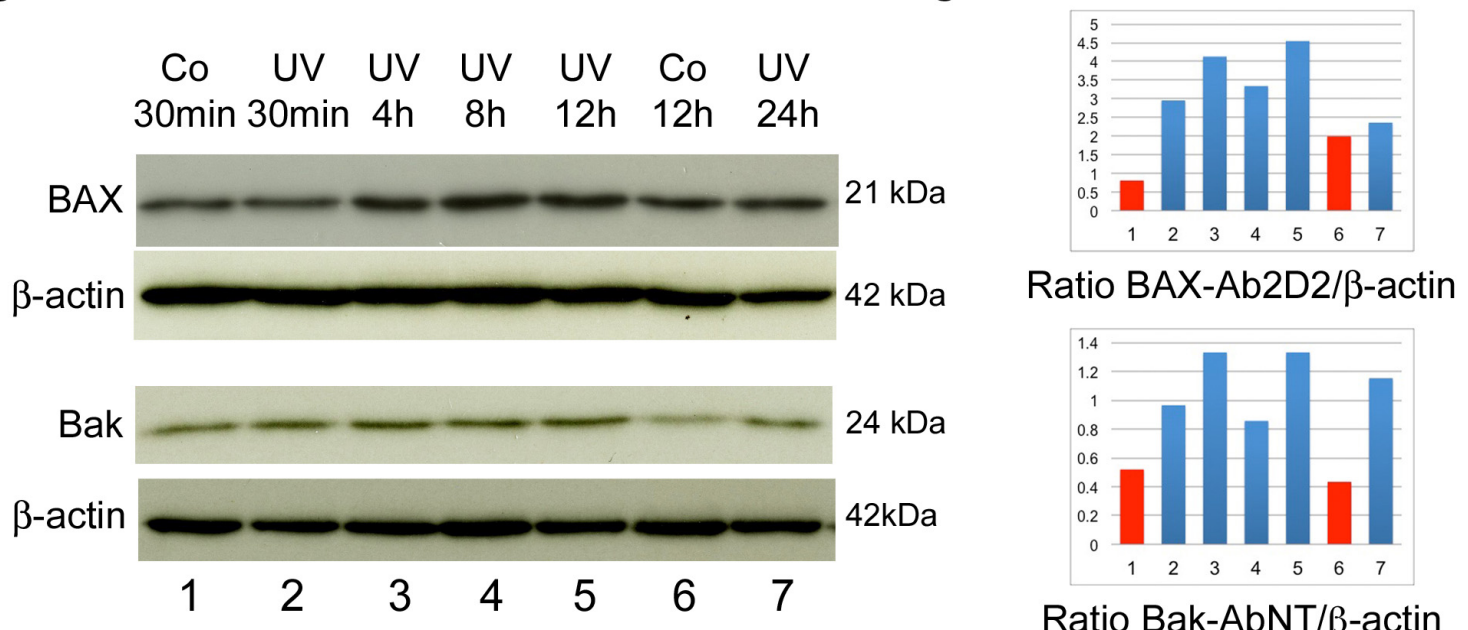

Ratio Bak-AbNT/ $\beta$-actin

Fig. S1 Validation of BAX-AbA20, BAX-Ab2D2 and Bak-AbNT antibodies using UV-irradiated canine keratinocytes

A. Immunohistochemistry with indicated antibody of keratinocytes collected at indicated time points after irradiation; Co 30min indicate non-irradiated controls collected at $30 \mathrm{~min}$ after irradiation; reactions were done using the indicated antibodies; B. Western blot of lysates of keratinocytes collected at indicated time points after UV irradiation reacted with BAX-Ab2D2, Bak-AbNT and for beta-actin; Co indicate non-irradiated controls collected at indicated time points; $\mathrm{C}$. Ratios of the density of the bands for BAX respectively Bak and beta-actin shown in B (same numbering); values of controls are indicated in red. 



\section{Danksagung}

Ich möchte mich besonders herzlich bei Prof. Franco Guscetti bedanken, der mir die Gelegenheit zur Anfertigung dieser so vielfältigen und spannenden Dissertation gegeben hat. Ausserdem bedanke ich mich für die gute Betreuung und Hilfe bei dieser Arbeit. Grazie mille!

Mein besonderer herzlicher Dank gilt auch an Prof. Andreas Pospischil, dem früheren Direktor des Institutes für seine Unterstützung bei dieser Arbeit und während meiner gesamten Zeit in der Pathologie.

Des weiteren möchte ich Prof. Lloyd Vaughan für seine oft auch spontane Hilfe im Labor herzlich danken.

Auch Martina Dettwiler danke ich sehr herzlich für die Unterstützung im Labor.

Vielen Dank an Sabina Wunderlin, ebenfalls für ihre Hilfe im Labor, bei der Immunhistochemie und besonders für die super schönen Leerschnitte von den TMAs.

Zum Schluss danke ich auch noch sehr herzlich meinen Eltern, meinem Bruder und meinem Freund Alex, die immer für mich da sind und mich immer unterstützt haben! 



\section{Curriculum Vitae}

Name, Vorname:

Geburtsdatum:

Geburtsort:

Nationalität:

Heimatort:

$9 / 1988-6 / 1993$

$9 / 1993-6 / 1998$

$9 / 1998-7 / 2003$

$7 / 2003$

$10 / 2003-10 / 2008$

$20 / 10 / 2008$

$1 / 2009-7 / 2013$
Croci, Martina

31.1.1982

Mendrisio

Schweiz

Mendrisio

Scuola elementare Mendrisio, Tessin, Schweiz

Scuola media Mendrisio/Scuola media Elvetico Lugano, Tessin, Schweiz

Liceo cantonale Lugano 1 (Schwerpunkt Biologie-Chemie), Tessin, Schweiz

Matura, Liceo cantonale Lugano 1, Tessin, Schweiz

Studium, Veterinärmedizin, Universität Zürich, Schweiz

Eidgenössisches Diplom Veterinärmedizin, Universität Zürich, Schweiz

Anfertigung der Dissertation

unter Leitung von Prof. Dr. med. vet. Franco Guscetti

am Institut für Veterinärpathologie Zürich der Vetsuisse Fakultät Zürich

Direktorin Prof. Dr. med. vet. Anja Kipar 